Beata Krzesinska-Żach

Uniwersytet w Biatymstoku

\title{
Dom rodzinny jako obszar zainteresowań współczesnej pedagogiki rodziny
}

\section{THE FAMILY HOME AS AN AREA OF INTEREST OF CONTEMPORARY FAMILY PEDAGOGY}

Family pedagogy focuses its interests around the issue of family upbringing, emphasizing the role of family and family home in human life.

The article presents the role of family home in child's life as the place of deep experiences, closeness and ties between the closest members of the family. The family home should create conditions for the proper development of the child and influence the form of childhood.

The research concerning the family home shows that it is perceived by children from the angle of the atmosphere prevailing in it (unfavourable atmosphere arouses the feeling of loneliness, favourable atmosphere gives the sense of emotional security, makes the family home a safe home).

Key words: family home, childhood, dysfunctional families, model of family home.

\section{Pojęcie domu rodzinnego i dzieciństwa}

Dom określa się jako mieszkanie, pomieszczenie mieszkalne, miejsce stałego zamieszkania, w którym znajdują się pokoje, okna, drzwi, sprzęty itp. Dom to także budynek, jakaś instytucja państwowa, społeczna, handlowa. Dom to rodzaj szczególnej bliskości i więzi między 
ludźmi. Znaczenie domu jest niepodważalne, i niczym nie zastąpione. Jest to przestrzeń, w której zamyka się egzystencja wspólnoty rodzinnej ${ }^{1}$.

Życie człowieka jest ściśle związane z rodziną i domem. Dom jest dla niego najważniejszym miejscem na ziemi. Kto nie ma domu, ten nie ma bliskich sercu osób, nie ma głębokich przeżyć, nie ma cudownych wspomnień, nie ma korzeni, nie ma do kogo i do czego wracać².

Dom jest też synonimem pewnego standardu życiowego. Spełnia niezastąpione funkcje ${ }^{3}$ :

a) funkcję ochrony - staje się miejscem zakorzenienia przez spełnianie potrzeby bezpieczeństwa i opieki;

b) funkcję odprężenia - w sytuacji, gdy większa część zajęć wykonywana jest poza domem, w nim można wypocząć i zregenerować siły;

c) funkcję emocjonalną - dom jest synonimem ciepła, w którym do głosu dochodzi życie uczuciowe człowieka;

d) funkcję komunikowania - dom jest miejscem do wymiany myśli, zwierzeń, do wpływania wzajemnie na siebie;

e) funkcję rozdzielania - w sensie pozytywnym; zdrowie psychiczne wymaga zachowania własnej autonomii, więc gdy w domu można mieć własny kącik, można na jakiś czas być tylko ze sobą.

Dom znajduje się w środku ludzkiego życia. I w domu każdy czuje się tak, jakby znajdował się w środku świata, więcej, dom - to symbol całego świata, swoiste centrum, w którym krzyżują się różne światy i wymiary. Symbolika domu jest bogata, bo człowiek na różne sposoby wiąże z nim swoją twórczość.

Dom rodzinny zawsze czeka otwarty, oczekuje na tych, którzy pragną do niego wrócić. Nie budynek, lecz ludzie, którzy w nim żyją, którzy go wypełniają i tworzą. Każdy w rodzinie ma swoje miejsce. Rodzina określa tożsamość swoich członków, jest gwarantem ciągłości dającej trwałą świadomość samej siebie.

Dom rodzinny:... to cała harmonia złączonych serc babci, wujka, rodziców i dzieci. To atmosfera wyciskająca i zostawiająca ślad, który nosi się w sobie przez całe życie i dzieli się nią z innymi ${ }^{4}$.

Mówiąc o domu rodzinnym mamy na uwadze dziecko, warunki jego rozwoju, stosunek do niego domowników czy sposób spędzania czasu wolnego. Rodzina kształtuje także te wszystkie cechy i dyspozycje

J. Wilk, Pedagogika rodziny. Zagadnienia wybrane, Lublin 2002.

2 L. Dyczewski, Rodzina twórca i przekazicielem kultury, Lublin 2003, s 51.

3 J. Wilk, Pedagogika..., op. cit. s. 64-65.

$4 \quad$ W. Kubik (red.), Jaka jesteś rodzino?, Kraków 1999, s. 78-79. 
dziecka, które decydować będą o jego przyszłości. To w rodzinie dziecko poddawane jest oddziaływaniu wychowawczemu, zatem rodzina kieruje procesem poznawania przez dziecko świata, przyrody i kultury, procesem rozumienia zjawisk i faktów otaczającego świata ${ }^{5}$.

$\mathrm{Z}$ domu rodzinnego wynosimy ład moralny, normy, zasady, prawdy, które stają się fundamentem życia każdego człowieka. Doświadczenie zdobyte w domu rodzinnym zostawia ślad w psychice, pamięci i duszy człowieka. Dziecko w rodzinie zaspokaja potrzebę przynależności, miłości i bezpieczeństwa, wszystko wyniesione z rodziny uważa za swoje, za dziedzictwo przodków i identyfikację z obecnym pokoleniem.

Charakterystyczny stan bliskości i mocne poczucie więzów między dzieckiem a rodzicami i otaczającymi ludźmi uznaje się za elementy tworzące sytuację właściwą i pożądaną. $\mathrm{Na}$ fundamencie więzi z bliskimi osobami buduje się u dorastającego dziecka znajomość świata.

Bliskość dziecka z jego rodzicami konkretyzuje się w życiu rodzinnym przyjmującym postać domu, w życiu którego uczestniczy dziecko. Dziecko ujawnia niedostrzegany, gdyż wcześniej nie skonkretyzowany sens domu rodzinnego; tym samym ubogaca świat domowych wartości ${ }^{6}$.

Dom to miejsce dziecka i dzieciństwa. To miejsce niepowtarzalnych przeżyć i formujących człowieka doświadczeń. Z domu wychodzi się na spotkanie drugiego człowieka, żyjącego „gdzieś”, w innym domu, w świecie. Człowiek, który wyszedł w świat, swoją postawą zaświadcza o jakości wewnętrznego życia domu. Świadczy o domu ujawniając swoją tożsamość ${ }^{7}$.

Dzieciństwo jest rzeczywistością, która ma swoje własne znaczenie (jest pełnowartościowym stadium ludzkiej egzystencji z własnym znaczeniem i z własną wartością). Człowiek aktualizuje już jako dziecko swoje własne, sobie właściwe i na swój sposób wartościowe postacie życia i poprzez te postacie życia ludzkiego spotyka on świat na swój własny sposób i to w sposób na tym etapie doskonały ${ }^{8}$.

Termin „dzieciństwo” obejmuje różnorakie treści. Najczęściej używane określenia: dzieciństwo jest przemijającą fazą życia człowieka; dzieciństwo jest obszarem wpływów edukacyjnych instytucji i grup

$5 \quad$ B. Dymara,Dom rodzinny wliteraturze i $\dot{z} y c i u$ dziecka, [w:] eadem (red.) Dziecko w świecie rodziny, Kraków 1998, s. 144.

$6 \quad$ M. Rembierz, Dom rodzinny jako osobliwy szczegót w świecie kulturowej bezdomności. Refleksje z filozofii człowieka, [w:] B. Dymara (red.) Dziecko wświecie rodziny, Kraków 1998, s. 127.

7 Ibidem, s. 131.

$8 \quad$ J. Wilk, Pedagogika..., op. cit., s. 117. 
zawodowych zajmujących się edukacją, dzieciństwo jest politycznym, ekonomicznym i światopoglądowym przygotowaniem młodego człowieka do przyszłego życia; dzieciństwo jest zespołem doświadczeń życiowych zdobywanych przez dzieci; dzieciństwo jest rzeczywistością dziecka, jego dziecięcym działaniem, doświadczeniem, przeżyciem, myśleniem; dzieciństwo jest dziecięcym losem, zapisującym się w biografii człowieka9 .

Z przytoczonych wypowiedzi wyłaniają się dwa stanowiska wobec problematyki dzieciństwa. W pierwszym przypadku dziecko traktowane jest jako obiekt poczynań rodziców, szkoły, kościoła, społeczeństwa. W tym wypadku pytamy o warunki rozwojowe jakie tworzą dzieciom dorośli i jak dzieci reagują na te warunki. Termin „dzieciństwo” oznacza tutaj świadczenia na rzecz dziecka i oddziaływania dorosłych na dzieci.

Drugie stanowisko akcentuje podmiotowość dziecka, która pojawia się jako społecznie zaakcentowane przeświadczenie o tym, że jest ono współpartnerem, współobywatelem, współkonsumentem. Przede wszystkim jednak podmiotowość dziecka oznacza, że jego rozwój dokonuje się dzięki aktywności małego człowieka, w jego kontaktach z rzeczywistością ${ }^{10}$.

Treść, charakter zdobywanych przez dziecko doświadczeń, przeżyć, jego zachowania - uwarunkowane są nie tylko poziomem i możliwościami rozwojowymi, stanem odczuwanych potrzeb ale przede wszystkim związane są ze środowiskiem. Zmienia się charakter, zakres, wymiar dziecięcych relacji, przeżyć, doświadczeń, zmienia się świat dziecka, pojawiają się nowe źródła tworząc nowe oblicza dzieciństwa współczesnych dzieci ${ }^{11}$.

Dzieciństwo traktowane jako kategoria społeczno-kulturowa:

a) uwzględnia istniejącą w literaturze pedagogicznej definicję dzieciństwa, przyjmując orientacją humanistyczną,

b) pozwala spojrzeć na dzieciństwo w kontekście zachodzących zmian w Polsce, związanych z procesem transformacji systemowej oraz różnych wydarzeń, zjawisk i procesów zachodzących w skali globalnej świata. Zmienia się, poszerza codzienna przestrzeń życia dziecka, zmienia się obszar i rodzaj kontaktów dziecka (poznawczych, społecznych, kulturalnych), pojawiają

9 B. Smolińska-Theiss, Dzieciństwo-obszary znane i nie znane, [w:] Prawa dziecka-deklaracje i rzeczywistość, Warszawa 1993, s. 97-98.

10 Ibidem, s. 98.

11 J. Izdebska, Dziecko w rodzinie u progu XXI wieku. Nowy wymiar dzieciństwa, „Rocznik Pedagogiki Rodziny”, R. 5, t. V. 
się nowe źródła o bardzo zróżnicowanym charakterze, ciągle zmieniające się źródła dziecięcych doświadczeńn ${ }^{12}$.

W rodzinach normalnie funkcjonujących, które stwarzają swoim dzieciom korzystne warunki do rozwoju, w których relacje między rodzicami a dziećmi cechuje wzajemna miłość, troska i zrozumienie-dzieciństwo tych dzieci można określić jako dzieciństwo rozwojowe.

Ale bywa też, że rodzina nie stwarza swoim dzieciom warunków do korzystnego rozwoju i wtedy ich dzieciństwo jest zagrożone. Zagrożone dzieciństwo to stan niekorzystnych czynników, środowiska rodzinnego dzieci - ich syndrom - który przejściowo lub trwale czyni to środowisko niewydolne wychowawczo. Jeśli ktoś nie zaznał bezpieczeństwa w dzieciństwie, nie będzie też go odczuwał jako osoba dorosła, a tym samym nie będzie w stanie zapewnić bezpieczeństwa swojemu dziecku (dzieciństwo osamotnione, w biedzie).

Dzieciństwo zniewolone ${ }^{13}$ - na skutek toczących się wojen, przemocy, biedy, głodu, chorób, patologii w rodzinie. Stanowią one źródło dziecięcych przeżyć, kumulujących się, niezwykle trudnych i bolesnych doświadczeń rzutujących na zachowania i los dziecka, które żyje w atmosferze zagrożenia.

Próba odpowiedzi na pytanie o kształt i znaczenie dzieciństwa i młodości upływających pod znakiem zniewalającej rodziny rodzi konieczność odtworzenia w ich przestrzeni trzech podstawowych sfer, (obszarów zniewolonego dzieciństwa): sfery zagrożenia, dewastacji oraz sfery wyboru (wartości).

Sferę zagrożenia zdaniem W. Theissa tworzą warunki, które są źródłem upokorzenia, cierpienia, tragedii, a w skrajnym wypadku przyczyną śmierci. Spoiwem łączącym wymienione okoliczności jest niebezpieczeństwo, które występować może jako zewnętrzne warunki tzw. wysokiego ryzyka, zwiększające prawdopodobieństwo wystąpienia przemocy czy jako tzw. sytuacja wysokiego stresu bądź też jako odczucie zagrożenia. Splot okoliczności tego typu można nazwać także sytuacją skrajną, którą charakteryzuje ustawiczne niebezpieczeństwo, bezsilność wobec istniejących zagrożeń oraz ich nieuchronność i nieznany czas trwania ${ }^{14}$.

Rzeczywistość rodziny dysfunkcyjnej niesie niebezpieczeństwa typu alkoholizm czy narkomania rodziców, przemoc w stosunku do dziecka, molestowanie seksualne itp.

\footnotetext{
12 Ibidem, s. 128-129

$13 \quad$ W. Theiss, Zniewolone dzieciństwo, Warszawa 1996. 
Sfera dewastacji (jako drugi obszar zniewolonego dzieciństwa) obejmuje czasowe lub trwałe zmiany, zachowania, odchylenia od normy, widoczne w psychofizycznym rozwoju jednostki, a także w jej społeczno-kulturowych relacjach z otoczeniem. Odtwarzanie sfery dewastacji wymaga, aby przedmiotem analiz uczynić formułowany przez dzieci i młodzież obraz rodziców i domu rodzinnego, opis krzywd i cierpień doznanych przez nie w rodzinie. Wynikiem tego może być obraz świata i ludzi młodych, przedwcześnie dojrzałych, ciężko doświadczonych przez los, pozbawionych radości życia.

Trzecia ze sfer zniewolonego dzieciństwa - sfera wartości wyboru jest przestrzenią psychologiczną, w której dokonuje się wybór określonych wartości, które zaaprobowane i zinternalizowane, decydują o ludzkim myśleniu i działaniu. Wybór ten, jest miarą stosunku między człowiekiem i światem (wybór wartości odsłania własne możliwości jednostki lub jej bezsilność wobec zniewalającego świata). Zapada on w sytuacjach skrajnych, ekstremalnych, które są niczym kamienie milowe: oznaczają drogę i wytaczają dalszy bieg życia ${ }^{15}$.

\section{Dom rodzinny w życiu dziecka - przegląd badań}

Problematyką dziecka i dzieciństwa zajmuje się wiele dyscyplin naukowych. Daje się zauważyć nowy, interdyscyplinarny dyskurs o dzieciństwie. Wyrazem zmiany podejścia do problematyki dzieci i dzieciństwa jest zdaniem H. Sünkera ${ }^{16}$, stopniowe kształtowanie się nowej strategii badawczej, którą w Niemczech określa się jako Kindheitforschung. W tym nowym podejściu widoczne jest odkrywanie dziecięcego świata, dziecięcego myślenia i działania.

Dzieciństwo to okres bardzo ważny w życiu każdego człowieka ze względu na kształtowanie się uczuć i relacji do otaczającego go świata (zwłaszcza tego, jaki tworzy rodzina).

Szczególnie w okresie przedszkolnym i wczesnoszkolnym zarówno matka, jak i ojciec stanowią istotne oparcie w procesie kształtowania się osobowości dziecka, jego świata myśli, dążeń, uczuć. Ważne jest, w jaki sposób dziecko odbiera postawy i zachowania rodziców w różnorodnych sytuacjach życia rodzinnego, jaki obraz rodziny ukształtuje w swojej osobowości. Jak postrzegają własną rodzinę dzieci w wieku wczesnoszkolnym?

\footnotetext{
$15 \quad$ Ibidem, s. 22-29.

16 Cyt. za D. Urbaniak-Zając, H. Sünker, Nowy dyskurs o dzieciństwie, „Problemy Opiekuńczo-Wychowawcze" 1997, nr 8.
} 
Obraz rodziny w przeżyciach dzieci. Badaniami objęto 185 dzieci w wieku wczesnoszkolnym (93 dziewcząt i 92 chłopców ${ }^{17}$. W badaniach autorka zastosowała:

a) tematyczną zabawę lalkami,

b) rysunek rodziny,

c) test niedokończonych zdań

Dziecięca wizja rodziny zaprezentowana w badaniach jest taka, jaką mu dyktują wewnętrzne potrzeby, dążenia oraz pragnienia. Badania wskazują, iż stosunki między rodzicami a dziećmi nie są najlepsze. Na rysunku „Moja rodzina” dzieci pomijają np. ojca, niekiedy matkę, ale najczęściej pomijają siebie. Pełną, aktualną rodzinę przedstawiło $63 \%$ dzieci z rodzin pełnych oraz $51 \%$ dzieci z rodzin rozbitych.

Badania wskazują również, że rodzice niewiele czasu poświęcają swoim dzieciom i nie zawsze jest on racjonalnie wykorzystany (pomimo wspólnego przebywania w domu nie prowadzą z nimi rozmów). Dzieci w zaaranżowanej zabawie lalkami nie potrafiły w większości (71\%) przedstawić takiej rodzinnej sytuacji, będącej przejawem serdeczności i bliskości rodzinnej.

Wypowiedzi dzieci na temat domu rodzinnego są bardzo różne. Krytyczna jest zwłaszcza ocena ojca zarówno wśród dzieci z rodzin rozbitych, jak i pełnych ${ }^{18}$. U dzieci z rodzin rozbitych wynika to z opinii matki, która przedstawia ojca jako człowieka negatywnego, oraz z własnych doświadczeń, przykrych przeżyć badanych dzieci. Negatywnie określiło ojca $26,7 \%$ badanych dzieci. Oto niektóre wypowiedzi „mało daje pieniędzy", ,jest niedobry, ponieważ nas opuścił, jest nerwowy”. Negatywnie określiły ojca także dzieci z rodzin pełnych (21,7\%), np. „mój tato jest leniuch i niedobry”, „gorszy od mamy jak się zdenerwuje”, „paskiem bije”. Wypowiedzi te są wynikiem panującej atmosfery w rodzinie na co dzień, stosunku ojca do dziecka i pozostałych członków rodziny. Te dzieci nie włączyły także ojca do sceny rodzinnej $\mathrm{w}$ zaaranżowanej zabawie lalkami ${ }^{19}$. Dzieci wielokrotnie w swoich wypowiedziach ujawniały, że są bite przez rodziców oraz, że rodzice często używają krzyku jako sposobu osiągnięcia celu.

Większość badanych dzieci (z rodzin pełnych) nie ma świadomości posiadania rodziców dla siebie, wzajemnej przynależności. Rodzina nie jest więc całkowicie spójna, jej członków nie łączą więzi emocjonalne, a to

17 Badania przeprowadzone w roku 1995/1996 w kilku szkołach Gdańska. E. Grochocińska, Rodzina w percepcji dzieci, [w:] J. Żebrowski (red.), Rodzina polska na przełomie wieków, Gdańsk 2000.

18 E. Grochocińska, Rodzina w percepcji dzieci..., op. cit., s. 161.

19 Ibidem, s. 162. 
świadczy, że jest rodziną zdezintegrowaną, jej właściwe funkcjonowanie jest zagrożone. Nieprawidłowe interakcje w rodzinie pomiędzy rodzicami a dziećmi, a także pomiędzy samymi rodzicami wskazują na konieczność wsparcia rodziny szczególnie w zakresie edukacji prorodzinnej, w tym głównie kultury pedagogicznej rodziców.

\section{Obraz domu rodzinnego - postrzegany przez dzieci z rodzin dysfunkcyjnych}

Potrzeba posiadania domu rodzinnego odczuwana jest przez każdego człowieka (zwłaszcza dziecka). Dom, który byłby miejscem bezpiecznym i spokojnym. Dom rodzinny jako teren życia dziecka i jego dzieciństwa, funkcjonowania rodziny, zapewnia stałość kontaktów, interakcji, spotkań, dialogu. Nie każdy jednak dom rodzinny jest dla dziecka miejscem bezpiecznym, miłości i troski ze strony osób najbliższych. Dom rodzinny, który przestaje być miejscem na spotkania rodzinne, bycie ze sobą, prowadzi do osłabienia więzi między członkami rodziny do osamotnienia dziecka ${ }^{20}$.

$\mathrm{Z}$ badań ${ }^{21}$ prowadzonych wśród dzieci 9-letnich wynika, że czują się one osamotnione w swoich domach rodzinnych w wyniku rozwodu rodziców (13\%); biedy, braku pieniędzy (70,3\%); na skutek niemożliwości wyjazdu na kolonie, na wycieczkę, na wczasy (61\%); kłótni w domu, pijaństwa rodziców, braku czasu dla dziecka.

Osamotnienie w rodzinnych domach dotyka także dzieci z rodzin $\mathrm{z}$ problemem alkoholowym ${ }^{22} \mathrm{i}$ związane jest głównie $\mathrm{z}$ dysfunkcyjnością rodziny, (częste awantury, pijaństwo rodziców, krzyki, przemoc i związane z tym zagrożenie, niepokój, lęk i wstyd przed innymi). Dzieciom tym towarzyszy także na co dzień bieda, niedostatek. Dom rodzinny jest postrzegany przez dzieci poprzez pryzmat panującej tam atmosfery, którą tworzy codzienność, określone relacje i zachowania członków rodziny, zwyczaje domu, różne sytuacje i wydarzenia życia rodzinnego.

Dla dzieci osamotnionych dom to przede wszystkim słabnąca więź emocjonalna, spowodowana dysfunkcjonalnością rodziny, patologią. W wypracowaniach na temat: Mój dom - najczęściej przedstawiały

$20 \quad$ J. Izdebska, Dziecko osamotnione..., op. cit., s. 138.

21 Badania własne w ramach pracy mgr S. Bazydło Dom rodzinny postrzegany przez dzieci 9-letnie z rodzin petnych i niepetnych pod kier. prof. J. Izdebskiej, Białystok 2002.

22 Badania przeprowadzone w Zakładzie Pedagogiki Społecznej pod kier. prof. J. Izdebskiej. 
one panującą w nim atmosferę: złą, wrogą, zagrażającą właściwemu rozwojowi ${ }^{23}$.

Osamotnione dzieci z rodzin rozwiedzionych swój dom rodzinny postrzegają w kontekście nowej dla nich sytuacji po odejściu ojca, jako miejsce, w którym ,jest teraz pustka”, ,jest bardzo smutno"24.

Odpowiedzią na tęsknotę za domem rodzinnym pełnym ciepła i miłości są marzenia dzieci osamotnionych. Marzenia dzieci osamotnionych z rodzin dysfunkcyjnych dotyczą domu, który zapewnia im poczucie bezpieczeństwa, miłość i silną więź emocjonalną. Nie będzie w nim alkoholu, pijanego ojca, kłótni między rodzicami, biedy w rodzinie, a one same nie będą czuły się osamotnione.

B. Dymara ${ }^{25}$ badając problem domu i rodziny w dziecięcym poetyzowaniu zauważa, że dzieci w swych wierszach przedstawiają bogactwo treści domu rodzinnego: radość, szczęście, ale także tęsknotę, wspólną więź i trud pracy, wprowadzają elementy bajkowe zaczerpnięte $\mathrm{z}$ filmów i książek. Niektóre dzieci zauważają głównie elementy zewnętrzne budynku, inne dom ujmują jako miejsce bezpieczne, do którego wraca się z przyjemnością, jeszcze inne rozszerzają symbolikę pojęcia domu na obszar małej i dużej Ojczyzny. Próbują również w swoich wierszach definiować pojęcie domu.

\section{Model rodzinnego domu}

Pojęcie wzoru czy modelu rodziny dotyczy określonych zachowań w rodzinie albo wyobrażeń postulujących te zachowania ${ }^{26}$. Antonina Kłoskowska ${ }^{27} \mathrm{w}$ odniesieniu do tematyki rodzinnej za model uznaje słowne, obrazowe lub jakiekolwiek symboliczne przedstawienie ludzkiego zachowania (instytucji, osobowości) mogące służyć za przykład i przedmiot odniesienia ocen i skonstruowane dla praktycznych celów społecznych.

\footnotetext{
$23 \quad$ J. Izdebska, Dom rodzinny..., op. cit., s. 140.

$24 \quad$ Cytowane badania mgr K. Klimczuk

25 B. Dymara, Dom rodzinny $w$ literaturze i życiu dziecka, [w:] Dziecko $w$ świecie rodziny, Kraków 1998, s. 140.

26 J. Izdebska, Dom rodzinny -jego wartość i znaczenie w życiu dziecka. Niektóre elementy modelu rodziny, [w:] eadem, Dziecko $w$ rodzinie u progu XXI wieku. Niepokoje i nadzieje. Białystok 2000.
}

27 A. Kłoskowska, Wzory $i$ modele $w$ socjologicznych badaniach rodziny, „Studia Socjologiczne" $1962 \mathrm{nr}$ 2, s. 24. 
Zdaniem F. Adamskiego ${ }^{28}$ wzór obejmuje „konkretnie ukształtowaną bądź kształtującą się rzeczywistość codziennego życia rodziny”, model zaś odnosi się do norm i wyobrażeń na temat owej rzeczywistości, konstruowanej przez badaczy. Autor wymienia elementy modelowe rodziny, stanowiące pewne grupy zagadnień:

1) wyobrażenia o małżeństwie i jego wartości w sferze normatywnej i w opinii środowiskowej, poglądy na charakter związku małżeńskiego, wymagane cechy od partnera do małżeństwa, trwałość i rozwiązalność związku małżeńskiego,

2) stosunki i powiązania wewnątrzmałżeńskie, rodzina wielka, mała, pozycje i role małżonków,

3) stosunki rodzice - dzieci: udział ojców i matek w procesie wychowawczym, metody wychowawcze i kierunki wychowania rodzinnego, kierunki i poziom kształcenia dzieci,

4) praca zawodowa kobiety zamężnej: stosunek do pracy zawodowej żony i matki poza domem, wpływ pracy zawodowej kobiety zamężnej na życie rodziny,

5) potrzeby i dążenia kulturalne rodziny: typ potrzeb i oczekiwań dotyczących ich zaspokojenia, typ realizowanych potrzeb, problem wspólnej konsumpcji wolnego czasu,

6) uznawany system wartości: zasady, normy etyczne regulujące wewnętrzne życie małżeńskie i rodzinne, aspiracje i dążenia życiowe w hierarchii uznawanych wartości,

7) rodzina a szersze grupy społeczne: rodzina a szkoła, rodzina a państwo,

8) czynniki dezintegrujące i dezorganizujące rodzinę oraz czynniki spoistości rodziny.

Jadwiga Izdebska ${ }^{29}$ dokonuje analizy wybranych elementów pożądanego modelu rodziny, ważnych z punktu widzenia wychowania dziecka w rodzinie. Przedmiotem analizy czyni następujące zagadnienia:

1) rodzina jako wspólnota życia i wychowania;

2) wychowanie rodzinne w kategorii spotkania i dialogu;

3) więź rodzinna jako ważny czynnik spoistości i integracji rodziny w procesie wychowania dziecka;

4) rodzina - jej miejsce i rola w społeczeństwie;

5) dom rodzinny - miejscem miłości, rozwoju i wychowania dziecka;

6) wypoczynek rodzinny - jego specyfika i wartość w życiu dziecka;

28 F. Adamski, Katolicki model rodziny a wspótczesna rodzina polska. Badania $w$ Katedrze Socjologii Rodziny, [w:] T. Kukołowicz (red.), Z badań nad rodzina, Lublin 1984, s. 190. 
7) media - integrujące rodzinę, wspomagające proces wychowania rodzinnego.

Wymienione elementy tego modelu warunkują określone funkcjonowanie wychowawcze i emocjonalne rodziny. Zwłaszcza warunki i atmosfera, jaką tworzy rodzina jako wspólnota osób poprzez naturalne zespolenie ludzi oraz więź emocjonalną między rodzicami i dzieckiem a także rodzeństwem. Autorka akcentuje wspólnotę jako jedność w różnych wymiarach (wspólnota życia, działania, zamieszkania, wspólnota emocjonalna, wychowawcza, kulturowa). Jako wspólnota rodzinna stwarza nieograniczone możliwości wzajemnego oddziaływania na siebie $^{30}$.

Czynnikiem scalającym, integrującym rodzinę jest więź rodzinna (strukturalno-przedmiotowa, osobowa oraz kulturowa). Należy dostrzegać znaczenie więzi osobowych, opartych na szacunku, życzliwości, miłości, tolerancji. Ukształtowanie trwałej więzi rodzinnej, głównie osobowej, emocjonalnej między dzieckiem a rodzicami, rodzeństwem oraz innymi członkami rodziny odgrywa ogromną rolę w rozwoju i wychowaniu dziecka. W rodzinie dziecko powinno uczyć się także bezinteresowności, poświęcenia, współpracy oraz innych cech ważnych w życiu społecznym, poznawać podstawowe normy moralno-społeczne, zwyczaje, tradycje, określony system wartości ${ }^{31}$.

Dom rodzinny jest również miejscem wspólnego przebywania, wzajemnych kontaktów, pracy i wypoczynku. Jego wartość tkwi między innymi w tym, że może to być miejsce na prawdziwe spotkanie najbliższych sobie emocjonalnie osób. Wzajemna miłość dzieci i rodziców, rodzeństwa, wspólnie realizowane cele, wspólne dążenia, wzajemna odpowiedzialność za siebie czynią dom rodzinny - domem bezpiecznym. Dom rodzinny powinien dawać poczucie bezpieczeństwa dla wszystkich członków rodziny, a jednocześnie być domem otwartym dla innych osób. Dom rodzinny to rodzinne rozmowy, wymagające czasu, wzajemnego słuchania siebie, wymiany myśli. Serdeczna czułość, wypowiadana w gestach, słowach rozbudza pragnienie bycia razem, zaprasza do wspólnych rozmów, wspólnej pracy i wypoczynku. Specyfika tego wypoczynku polega na tym, że dotyczy on najbliższych sobie emocjonalnie osób, ma charakter naturalny, nieformalny, realizuje się poprzez codzienne obcowanie ze sobą, spotkania, dialog, interakcje między członkami rodziny (akcentuje się wartość wychowawczą wypoczynku dla całej rodziny). Wypoczynek rodzinny powinien pełnić rolę inspirującą, przejawiającą się w budzeniu zainteresowań

$30 \quad$ Ibidem, s. 235 .

$31 \quad$ Ibidem 
dzieci i innych członków rodziny, w kształtowaniu postaw, rozwijaniu aspiracji i potrzeb. Telewizja i inne media kształtują również model rodzinnego domu. Rodzicom przekazują wiedzę z zakresu pedagogiki, psychologii, inspirując ich do określonej pracy wychowawczej z dzieckiem, do wykorzystywania zdobytej wiedzy w konkretnych sytuacjach wychowawczych, w procesach integracji rodziny poprzez wspólny, rodzinno-domowy odbiór przekazów medialnych. Wspólne oglądanie przez rodziców i dzieci programów telewizyjnych lub innych przekazów medialnych powinno mieć istotne znaczenie wychowawcze, ponieważ dostarcza tematów do rodzinnej rozmowy, stając się źródłem przeżyć i wspólnotowych doświadczeń kulturalnych ${ }^{32}$.

Model rodzinnego domu zakłada, że dom to jedyne miejsce na ziemi, miejsce nie tylko fizyczne, ale i przestrzeń duchowa, wypełniona zrozumieniem i miłością, pozwalająca znosić trudy życia. To przystań, schronienie, świat bliski i przyjazny, miejsce dające poczucie bezpieczeństwa, spokoju, odpoczynku, schronienia ${ }^{33}$.

Słowa kluczowe: dom rodzinny, dzieciństwo, rodziny dysfunkcyjne, model rodzinnego domu.

\section{Bibliografia:}

1. Adamski F., Socjologia matżeństwa i rodziny, Warszawa 1984.

2. Cudak H., Rodzina polska u progu XXI wieku, Łowicz 1997.

3. Duda M. (red.), Rodzina wobec zagrożeń, Kraków 2008.

4. Dyczewski L., Rodzina twórca i przekazicielem kultury, Lublin 2003.

5. Dymara B., Dziecko w świecie rodziny, Kraków 1998.

6. Gorbaniuk J., Rodzina wobec wspótczesnych wyzwan społeczno-kulturowych, Lublin 2009.

7. Izdebska J., Dziecko osamotnione $w$ rodzinie. Kontekst pedagogiczny, Białystok 2004.

8. Izdebska J., Dziecko w rodzinie u progu XXI wieku. Niepokoje i nadzieje, Białystok 2000.

9. Jacyno M., Szulżycka A., Dzieciństwo, doświadczenie bez świata, Warszawa 1999.

10. Kwak A., Rodzina w dobie przemian. Matżeństwo i kohabitacja, Warszawa 2005.

11. Kawula S., Brągiel J., Janke A. W., Pedagogika rodziny. Obszary i panorama problematyki, Toruń 2009.

12. Kocik L., Wzory matżeństwa i rodziny: od transformacji jednorodności do wspótczesnych skrajności, Kraków 2002.

32 Ibidem.

33 Z. Płoszyński, Myśl pedagogiczna Korczaka - Kochać dziecko $w$ rodzinie, [w:] T. Wróblewska (red.), Aktualność idei J. Korczaka, Koszalin 1993, s. 130. 
13. Kozłowska-Świątkowska E., Zapachy dzieciństwa, Białystok 2003.

14. Kubik W. (red.), Jaka jesteś rodzino?, Kraków 1999.

15. Liberska H., Wybrane problemy wspótczesnych matżeństw i rodzin, Warszawa 2011.

16. Ładyżyński A., Rodzina we wspótczesności, Wrocław 2009.

17. Muchacka B. (red.), Rodzina w kontekście współczesnych problemów wychowania, Kraków 2008.

18. Rembierz M., Dom rodzinny jako osobliwy szczegót w świecie kulturowej bezdomności. Refleksje z filozofii człowieka, [w:] B. Dymara (red.), Dziecko w świecie rodziny, Kraków 1998.

19. Skreczko A., Wychowanie domowe, Białystok 2007.

20. Slany K., Alternatywne formy życia matżeńsko-rodzinnego w ponowoczesnym świecie, Kraków 2002.

21. Smolińska-Theiss B., Dzieciństwo w matym mieście, Warszawa 1993.

22. Theiss W., Zniewolone dzieciństwo, Warszawa 1996.

23. Tyszka Z. (red.), Współczesne rodziny polskie - ich stan i kierunki przemian, Poznań 2003.

24. Wilk J., Pedagogika rodziny. Zagadnienia wybrane, Lublin 2002. 